\title{
A case-control study of the role of cold symptoms and other historical triggering factors in asthma exacerbations
}

\author{
Susan M Tarlo MB BS ${ }^{1}$, Irvin Broder MD ${ }^{1}$, Paul Corey $\mathrm{PhD}^{1}$, Moira Chan-Yeung $\mathrm{MD}^{2}$, \\ Alexander Ferguson $\mathrm{MD}^{2}$, Allan Becker $\mathrm{MD}^{3}$, Peter Warren MB BS ${ }^{3}, \mathrm{~F}$ Estelle R Simons $\mathrm{MD}^{3}$, \\ Christopher Sherlock $\mathrm{MD}^{2}$, Marilyn Okada $\mathrm{MA}^{1}$, Jure Manfreda $\mathrm{MD}^{3}$ \\ ${ }^{1}$ University of Toronto, Toronto, Ontario; ${ }^{2}$ University of British Columbia, Vancouver, \\ British Columbia; and ${ }^{3}$ University of Manitoba, Winnipeg, Manitoba
}

SM Tarlo, I Broder, P Corey, et al. A case-control study of the role of cold symptoms and other historical triggering factors in asthma exacerbations. Can Respir J 2000;7(1):42-48.

BACKGROUND: Asthma exacerbations can be provoked by many triggers such as allergens, respiratory irritants and viral infections. The relative importance of these has not been prospectively documented in a case-control study.

OBJECTIVE: To assess the relative importance of colds and other nonclimatic historical triggers of asthma exacerbations. METHODS: One hundred and nineteen adults and children with asthma in two Canadian cities participated in a one-year study of the role of exacerbating factors in asthma. Among these, 36 pairs ( 21 adult, 15 children) completed the casecontrol study. Patients were considered cases if they developed an acute asthma exacerbation and notified the centre within $24 \mathrm{~h}$ to allow the completion of a questionnaire and viral studies (cultures of nasopharyngeal swabs and serology). Control people with asthma were matched for sex, age and area of residence, had no exacerbation during the preceding four weeks and participated within $48 \mathrm{~h}$ of the case patients.
RESULTS: Case patients versus control patients had a mean age of 22 years versus 20 years, $50 \%$ versus $55 \%$ were male, and $92 \%$ versus $86 \%$ had at least one positive aeroallergen skin test. Cases were more likely to have taken regular inhaled steroids (63\% versus 33\%, $\mathrm{P}<0.002$ ). Cases were more likely to report the following within the previous week: fever $(\mathrm{P}<0.001)$, sore throat $(\mathrm{P}<0.001)$, increase in nasal symptoms $(\mathrm{P}<0.01)$, increased dust exposure $(\mathrm{P}<0.05)$, exposure to others with a cold $(\mathrm{P}<0.001)$ and, over the previous year, increased passive smoke exposure $(\mathrm{P}<0.05)$. Viral cultures and paired serology were negative.

CONCLUSIONS: Symptomatic colds were the most common trigger of asthma exacerbations in the winter and spring, while a transient increase in dust exposure was also identified as a significant trigger. The association with chronic, passive smoke exposure and the use of inhaled costicosteroid medications likely reflected less stable pre-study asthma in those with exacerbations.

Key Words: Asthma; Asthma triggers; Colds; Respiratory viral infections; Serology; Viral cell culture

Pour le résumé, voir page suivante

Correspondence and reprints: Dr Susan M Tarlo, Gage Occupational and Environmental Health Unit, 223 College Street, Toronto,

Ontario M5T 1R4. Telephone 416-978-5883, fax 416-978-2608, e-mail susan.tarlo@ utoronto.ca 


\section{Une étude cas-témoins du rôle des rhumes symptomatiques et des autres facteurs histori- quement connus pour exacerber l'asthme}

HISTORIQUE : Les exacerbations de l'asthme peuvent être provoquées par de nombreux facteurs précipitants tels que les allergènes, les irritants respiratoires et les infections virales. L'importance relative de ces derniers n'a pas été documentée de façon prospective dans une étude cas-témoins.

OBJECTIF : Évaluer l'importance relative des rhumes et des autres facteurs climatiques historiquement connus pour exacerber l'asthme.

MÉTHODES : Cent dix neuf adultes et enfants asthmatiques de deux villes canadiennes ont participé à une étude d'une année sur le rôle des facteurs précipitants dans l'asthme. Parmi ces personnes, 36 paires (21 adultes, 15 enfants) ont participé à cette étude castémoins jusqu'à la fin. Les patients étaient considérés comme « cas » s'ils développaient une exacerbation aiguë de l'asthme et s'ils avertissaient le centre dans les 24 heures pour pouvoir remplir un questionnaire et subir des tests viraux (cultures des prélèvements rhino-pharyngiens et sérologie). Les « témoins » asthmatiques étaient appariés pour le sexe, l'âge et le lieu de résidence, n'avaient pas subi d'exacerbation au cours des quatre semaines précédentes et étaient inclus dans l'étude dans les 48 heures suivant l'inclusion des patients considérés comme cas.

RÉSULTATS : Le groupe des cas par rapport au groupe des témoins avaient une moyenne d'âge de 22 ans par rapport à 20 ans, $50 \%$ des cas étaient des hommes par rapport à $55 \%$ des témoins et $92 \%$ des cas par rapport à $86 \%$ des témoins avaient au moins un test cutané aux aéroallergènes positif. Les cas semblaient avoir pris plus souvent des stéroïdes en inhalation sur une base régulière que les témoins ( $63 \%$ par rapport à $33 \%, \mathrm{p}<0,002$ ). Les cas semblaient avoir rapporté plus souvent les symptômes suivants au cours de la semaine précédente : fièvre $(\mathrm{p}<0,001)$, mal à la gorge $(\mathrm{p}<0,001)$, augmentation de la rhinorrhée $(\mathrm{p}<0,01)$, augmentation d'une exposition à la poussière ( $\mathrm{p}<0,05)$, exposition à d'autres personnes enrhumées $(\mathrm{p}<0,001)$ et, au cours de l'année précédente, augmentation d'une exposition passive à la fumée de tabac $(\mathrm{p}<0,05)$. Des cultures virales et une sérologie appariée étaient négatives.

CONCLUSIONS : Les rhumes symptomatiques déclenchaient le plus souvent les exacerbations de l'asthme en hiver et au printemps, alors qu'une augmentation passagère de l'exposition à la poussière a aussi été identifiée comme un facteur précipitant significatif. L'association avec l'exposition passive et chronique à la fumée de tabac et l'utilisation de corticostéroïdes en inhalation avait tendance à refléter un asthme plus sévère chez les sujets qui avaient subi des exacerbations.
$\mathrm{R}$ espiratory viral infections have been reported to trigger up to $80 \%$ to $85 \%$ of childhood asthma episodes (1-4). In adults, they have been shown to increase airway responsiveness, even in subjects without clinical asthma (5), especially in allergic subjects (6); in mice, viral infections can enhance airway sensitization to allergen (7). Some, but not all studies have shown an association with acute asthma exacerbations (8-11), especially when newer, sensitive virological detection methods are used (8). Beasley et al (9) identified a viral respiratory tract infection in $10 \%$ of 178 exacerbations of asthma in 31 adults, but found a higher proportion $(36 \%)$ of severe exacerbations to have such an association.

In our previous study of adults with asthma (10), only $3 \%$ of exacerbations were associated with confirmed viral infections and $9 \%$ with symptomatic colds. Symptomatic colds were more common among adults with asthma than their nonasthmatic spouses (10), particularly in the spring, summer and fall. A recent study of severe exacerbations of asthma in 33 patients presenting to an emergency room (11) also failed to detect objective evidence of viral infections using culture, serology and rapid antigen detection by an immunofluorescent technique used on nasal swabs. Overall, 56\% of the visits were associated with one or more symptoms suggestive of a viral illness, with rhinorrhea in $38 \%$ of patients, sore throat in $9 \%$ and fever in $15 \%$. Nevertheless, the newer technique of reverse transcriptase-polymerase chain reaction used with culture has identified viruses, most commonly rhinovirus, in $80 \%$ to $85 \%$ of wheezing episodes in children (4), suggesting that older methods were not sufficiently sensitive.

The timing of the onset of wheezing in children has been shown to be $43 \pm 7 \mathrm{~h}$ (mean \pm standard deviation) after the first upper respiratory symptoms of a respiratory viral infection, longer than the typical timing of acute asthmatic responses associated with an allergen exposure (12). Further evidence suggesting that such episodes in children relate more to viral infections than to allergic responses comes from a casecontrol study of South African asthmatic children with and without acute exacerbations (13). There was a strong association of acute exacerbations with symptomatic colds but no association with changes in pollen or fungal spore counts, or with known allergen exposure. Similar findings were reported in a study of Norwegian children with acute asthma exacerbations (3). An epidemiological study also suggested an association between hospital admissions for asthma and upper respiratory infections (14).

The development of a large, one-year prospective study to examine environmental factors in a cohort of adults and children provided the opportunity to design a case-control study within this group to examine some triggers, colds especially, of acute asthma exacerbations. The objective of the study was to assess the relative frequency of reported symptomatic colds associated with exacerbations of asthma, compared with nonseasonal triggers such as dust and second-hand tobacco smoke. The larger, one-year study presented the opportunity to match people with asthma during exacerbations with people with asthma from the same geographic region who did not have an exacerbation at that time, and therefore control for the effects of climate. In addition, the information collected for the one-year study provided prospective background data to characterize patients and control subjects in a more detailed manner than available in other acute studies. 


\section{PATIENTS AND METHODS}

General study design: A case-control study was performed to assess nonclimatic causes of individual acute exacerbations of asthma. It was part of a larger, one-year panel study performed to identify factors which trigger acute exacerbations of symptoms in patients with asthma. Two Canadian cities in geographically different regions of Canada were selected for the study - Vancouver, on the Pacific coast and Winnipeg, on the Prairies.

Patients: Patients with a history compatible with asthma and evidence of reversible airflow limitation or airway hyperresponsiveness were recruited if they were over seven and less than 55 years of age and lived within $10 \mathrm{~km}$ of the clinics. Patients with heart disease, chronic lung disease such as bronchiectasis and emphysema, or occupational asthma, were excluded. In both cities, patients were recruited from university hospital respiratory and allergy clinics. A child was defined for this study as a patient under age 13 years.

\section{Baseline assessments}

Visits to the clinic: At the initial interview, an entry questionnaire was completed that included details concerning the home environment and exposure to potential asthma triggers such as animals, cigarette smoke and occupational sensitizers or irritants. Home visits were made to determine levels of exposure to dust mite and cat allergens, and were the focus of a separate report (15). Lung function tests, including methacholine challenge tests, were carried out as described previously (16). The patients were instructed on the correct completion of the diary card for the one-year study. The diary card included a record of their day and night symptoms on a severity scale ranging from 0 to 3 for each symptom, medication use (recorded number of puffs of inhaled steroid were later adjusted for analyses to the equivalent of $50 \mu \mathrm{g}$ of beclomethasone per puff) and peak flow rates measured twice daily (16), in the morning and evening before the use of medications. After two weeks of practice to ensure adequate completion of the diaries, the patients started the one-year study.

Allergy skin testing: Epicutaneous (prick) tests were performed on the volar surface of the forearm with 13 common allergens (tree mixture, grass mixture, weed mixture, redroot pigweed, sorrel, English plantain, Lamb's quarters, mold mixture, feather mixture, cat and dog dander, Dermatophagoides farinae and Dermatophagoides pteronyssinus) with a negative control (normal saline) and a positive control of histamine at $1 \mathrm{mg} / \mathrm{mL}$. The results were read at $15 \mathrm{mins}$. The wheals were outlined using a ballpoint pen, and the outlines were transferred to the record sheet using clear adhesive tape. The longest diameter of the wheal and its perpendicular diameter were measured and the average was used for analysis. A wheal diameter of $3 \mathrm{~mm}$ or greater than the negative control was considered a positive reaction. For this study, atopy was defined as the presence of one or more positive skin tests.

Case-control selection and assessments: The case-control study within the one-year study was designed to examine the relative importance of viral upper respiratory infections (manifest as symptomatic colds), compared with other nonclimatic historical triggers on acute exacerbation of asthma. A patient with an acute exacerbation of asthma was considered a case. An acute exacerbation of asthma was defined as meeting at least one of the following criteria: hospitalization for the treatment of asthma; emergency room visit for the treatment of asthma; unscheduled visits to a physician's office for the treatment of asthma; or increase in asthma symptoms during the day and night for more than $48 \mathrm{~h}$ and no reponse to the patient's usual inhaled bronchodilators and inhaled corticosteroid medications. Whenever they had acute exacerbation of asthma as defined above, the patients were instructed to telephone the nurse coordinator. A control subject was identified from the patients in the panel study if he or she did not have an exacerbation in the previous four weeks and was matched (within $48 \mathrm{~h}$ of the case identification), by the place of residence, age and sex. In this study, only the first reported asthma exacerbation was used for cases. Subjects who were included as cases could not be included in the analyses at a different time as controls and vice-versa. When the case and the control had been identified, the nurse coordinator visited each panelist at home or in the hospital and obtained the following.

- Responses to a questionnaire identifying exposure to triggering factors during the previous week. Questions included "Were you exposed to an unusual degree to dusts/cigarette smoke/sprays/cold air/someone with a cold/special house cleaning in the past week?"

- Nasal secretion or throat swab for viral culture

- Collection of blood for viral serology during the acute exacerbation and again during convalescence (six weeks after the onset).

\section{Viral studies}

Serology: Antibody assays for viruses were carried out using complement fixation, which measures both immunoglobulin $\mathrm{G}$ and immunoglobulin $\mathrm{M}$ antibodies. The antigens for all assays were supplied by Bartels Company (Bellevue, Washington). Acute and convalescent (after six weeks) sera from each patient were run in the same assay. The sera were assayed for antibody to influenza A and B, adenoviruses, respiratory syncytial virus, parainfluenza viruses 1,2 and 3 , and Mycoplasma pneumoniae.

The complement fixation assays were carried out according to standard methods (17). Dilutions were twofold, with a starting dilution of 1:4; a dilution of less than 1:4 was considered negative.

Virus culture: The nasopharyngeal area was swabbed. Swabs were transported in minimal essential medium containing bovine serum albumin, HEPES buffer, penicillin, gentamicin, amphotericin B and L-glutamine. Specimens were stored at $4{ }^{\circ} \mathrm{C}$ and transported on ice to the virology laboratory.

The swabs were vortexed in the transport medium before inoculation. The medium was then inoculated into human foreskin fibroblast cells, Hep-2 cells and Rhesus monkey 
TABLE 1

Features of case and control groups and season of exacerbations

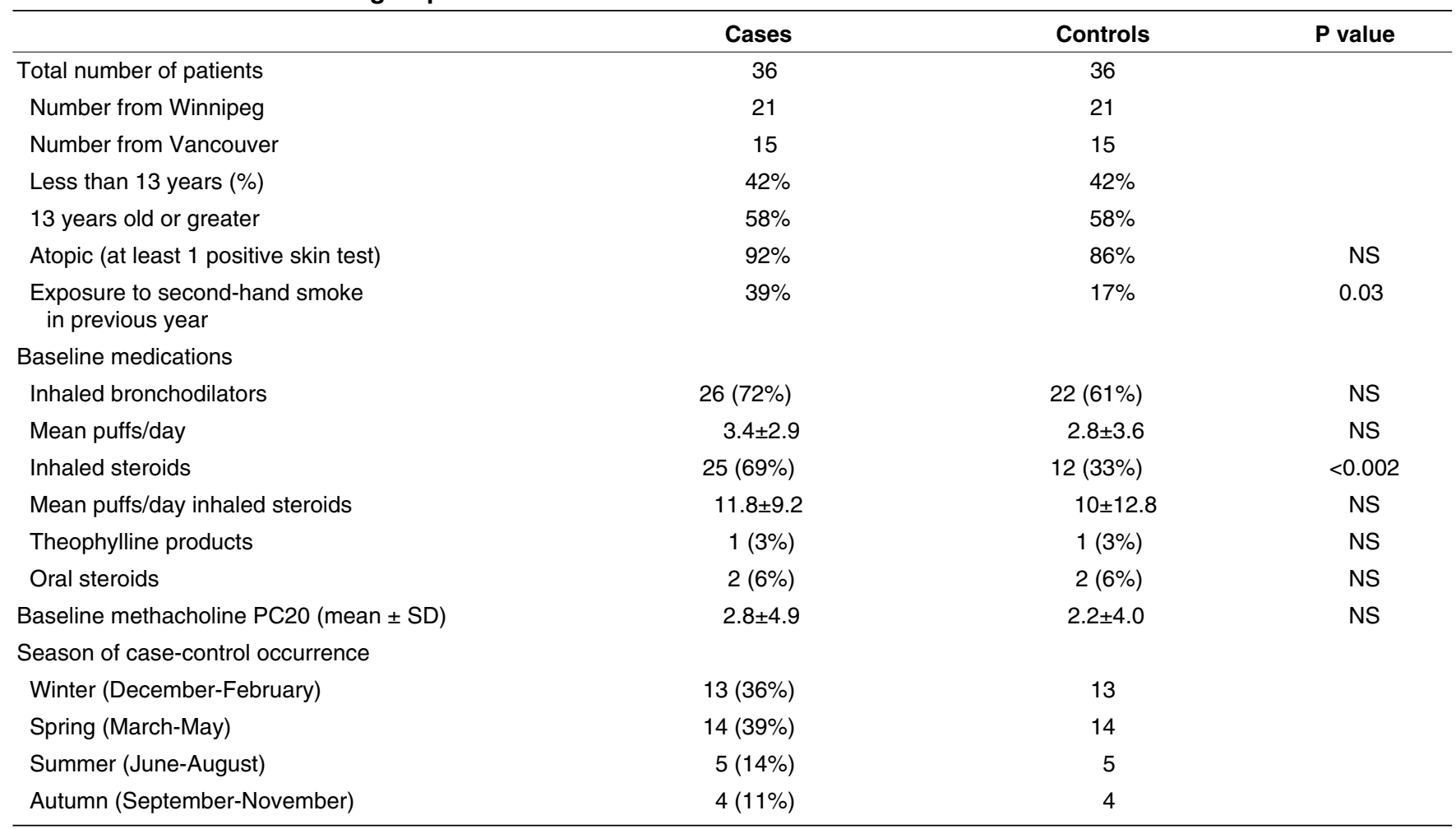

NS Not significant

kidney (RMK) cells and incubated for 14 days. The RMK cells were incubated at $33^{\circ} \mathrm{C}$ in serum-free medium. These cells were hemadsorbed at three, seven, 10 and 14 days postinoculation. If hemadsorption was negative, one tube of RMK cells was blind-passaged at day 7 .

When a suspicious cytopathic effect (CPE) was identified in cell culture or hemadsorption was positive, cells were removed from the positive tube and examined for viral antigen by immunofluorescence. The following viral antigens were sought: group common adenovirus, respiratory syncytial virus, influenza $A$ and B, and parainfluenza types 1, 2 and 3. All immunofluorescence reagents used monoclonal antibodies supplied by Bartels Company. If the CPE was not characteristic for these viruses or the immunofluorescence was negative, electron microscopy was carried out to identify other potential viruses. Picornaviruses were identified by characteristic $\mathrm{CPE}$ and electron microscopy; rhinoviruses were distinguished from enteroviruses by the acid lability test.

Statistical analyses: Results were analyzed using the SAS statistical software package (version 6.12, SAS Institute, Cary, North Carolina) for a personal computer. The paired $t$ test was used to compare the mean values of variables between case and control patients. The sign test comparison was used on the proportions of case and control patients in various categories.

\section{RESULTS}

A total of 119 adults and children were included in the one-year study in Winnipeg and Vancouver. Among the study population, 36 patients with acute exacerbations of their asthma completed the case-control aspect of the study and were matched with 36 other study patients of similar age from the same city who did not have a concurrent acute exacerbation (Table 1).

Fifteen of these pairs lived in Vancouver and 21 in Winnipeg. The characteristics of the case and control patients were similar in the two cities. Fifteen pairs were children (younger than 13 years). Females and males were equally distributed between both groups. Allergy skin test responses to individual aeroallergens were not significantly different in cases compared with control patients; $92 \%$ of cases and $86 \%$ of controls had at least one positive skin test to a common allergen extract. Before the exacerbation (on entry to the one-year study), cases were more likely than control patients to be taking regular inhaled steroid medications, $69 \%$ versus $33 \%$ $(\mathrm{P}<0.002)$. Baseline airway responsiveness to methacholine, however, was not significantly different between case and control patients.

Case patients were also more likely than controls to report exposure to second-hand cigarette smoke over the previous year $(\mathrm{P}<0.03)$ in the initial questionnaire, before starting the one-year study. As expected, because each patient could be 
TABLE 2

Characteristics of exacerbations and preceeding noted exposures in case and control patients

\begin{tabular}{|c|c|c|c|}
\hline & Case patients $(n=36)$ & Control patients $(n=36)$ & $P$ value \\
\hline \multicolumn{4}{|l|}{ Symptoms preceeding exacerbation* } \\
\hline Cough & $26(72 \%)$ & $1(3 \%)$ & $<0.001$ \\
\hline Sore throat & $19(53 \%)$ & $1(3 \%)$ & $<0.001$ \\
\hline Nasal symptoms & $23(64 \%)$ & $12(33 \%)$ & $<0.01$ \\
\hline At least 2 of above & $17(47 \%)$ & $1(3 \%)$ & $<0.01$ \\
\hline Exposed to someone with a cold & $20(56 \%)$ & $6(17 \%)$ & 0.001 \\
\hline Increased dust & $11(31 \%)$ & $4(11 \%)$ & $<0.05$ \\
\hline Special house cleaning & $8(22 \%)$ & $3(8 \%)$ & NS \\
\hline Seasonal pollen exposure & $9(25 \%)$ & $6(17 \%)$ & NS \\
\hline Increased medications & $29(81 \%)$ & $1(3 \%)$ & $<0.001$ \\
\hline Phoned physician & $11(31 \%)$ & $0(0 \%)$ & $<0.001$ \\
\hline Saw family doctor & $12(33 \%)$ & $0(0 \%)$ & $<0.001$ \\
\hline Went to the emergency department & $6(17 \%)$ & $0(0 \%)$ & 0.01 \\
\hline \multicolumn{4}{|l|}{ Medications increased/added } \\
\hline Inhaled bronchodilator & 36 (100\%) & $6(17 \%)$ & $<0.001$ \\
\hline Inhaled steroid & $26(72 \%)$ & $5(14 \%)$ & $<0.001$ \\
\hline Theophylline & $1(3 \%)$ & $0(0 \%)$ & NS \\
\hline Oral steroids & $10(28 \%)$ & $0(0 \%)$ & 0.001 \\
\hline
\end{tabular}

${ }^{\star} P$ values were expected to show significant differences in asthma symptoms between case and control groups because these were included in the criteria for defining case patients

recruited no more than once as an exacerbation case in this part of the study, most exacerbations occurred in the first half of the one-year study (December to February, 36\% and March to May $39 \%$ ), while only $25 \%$ occurred in summer and fall (Table 1).

Two-thirds of the cases claimed that they were aware of the cause of their exacerbation (Table 2). Cases were more likely than control patients to report exposure to others with a cold within the preceding week $(\mathrm{P}<0.001)$, and had a greater frequency of reported fever $(\mathrm{P}<0.001)$, sore throat $(\mathrm{P}<0.001)$ and increased or recent onset of nasal symptoms $(\mathrm{P}<0.01)$ in the week preceding the asthma exacerbation. Sixteen cases (44\% of all cases) had at least two of three symptoms (fever, sore throat, nasal symptoms), which was suggestive of viral upper respiratory infections. Nevertheless, paired viral serology and throat swabs for viral culture were negative in all cases. Case patients with cold symptoms compared with those without did not differ with respect to baseline reports of second-hand smoke exposure or inhaled steroid usage.

Case patients more often reported increased residential dust exposure for the week before the date of the acute exacerbation (11 case patients versus four control patients) $(\mathrm{P}<0.05)$, but there was no difference in skin test responsiveness to dust mites between case and control patients ( $43 \%$ of cases and $46 \%$ of controls were skin test positive to an extract of Dermatophagoides farinae). No other significant environmental differences were identified between case and control patients.

The severity of the exacerbation was such that six (17\%) of the patients went to an emergency department, 33\% visited the family doctor and $30 \%$ telephoned their doctor. None were admitted to hospital. Eighty per cent increased their asthma medications (Table 2).

Subsequently, the diary records of the case patients, recorded over one year as part of their participation in the panel study were examined. Thirty-five of the 36 cases had been compliant in maintaining regular diary records before and during the period of their acute exacerbation in the casecontrol component of the study (diary records were not reviewed for control patients). Diary records during the time of acute asthma exacerbations reflected an increase in at least two of the following three symptoms: nose symptoms, throat symptoms and fever in 17 cases, either starting the same day or one to four days before the acute asthma exacerbation. The records indicated similar severity for the asthma exacerbation in those with and without associated cold symptoms; $82 \%$ and $88 \%$, respectively, had an increase in at least two of three asthma symptoms (cough, wheeze, dyspnea). There was a trend to an increased severity of the maximum increase in symptom score in those with cold symptoms: $82 \%$ versus 
$61 \%$ had a symptom score increase of 2 or 3 . However, those without cold symptoms showed a trend to greater increase in medications, and did not differ in their percentage maximum peak flow fall from baseline values during the exacerbation (data not shown).

\section{DISCUSSION}

The design of this study had an advantage over most previous studies of acute asthma exacerbations because of the availability of detailed data from both case and control patients before the acute event, as part of the one-year study. In addition, the acute event was rapidly characterized by a patient visit within $48 \mathrm{~h}$ and is likely to be more accurate than retrospective questionnaires. This study confirms the importance of symptomatic colds as triggers of asthma exacerbations in a population of children and adults. Previous studies suggesting that symptomatic respiratory viral infections are especially important in relatively severe exacerbation of asthma are also supported by our findings that most subjects contacted a physician because of the severity of symptoms.

Potential sources of bias in this study were the inability to blind the nurse coordinators, who conducted the interviews, as to which patients were cases, although the nurse coordinators were trained carefully to reduce this risk. In addition, there may have been recall bias from case patients themselves versus controls patients regarding recent exposures. Because this study assessed acute events, the test-retest validity of the questionnaires could not be assessed in these patients.

The high proportion of symptomatic colds in this study (44\%) may in part be because of the timing of the recruitment. Recruitment was restricted to a defined number of cases and occurred relatively early in the course of the oneyear panel study. Each patient could not be included more than once as a case or a control subject. This accounts for the seasonal distribution, mainly from November to May (Table 1), coinciding with the first six months of the study and with the time when viral infections would be expected to be more prevalent. This period also precedes the peak of seasonal pollen and fungal spore exposure.

It has been suggested $(10,11)$ that the difference between reports of colds in children and adults with asthma might relate to differences in viral strains with patient's age. There are particular difficulties in the detection of rhinoviruses and coronaviruses using standard serological and culture methods. Rhinoviruses are the most frequent cause of the common cold. They are also one of the most commonly identified viruses associated with asthma exacerbations in children and adults. However, there are at least 100 serotypes which make serological diagnosis difficult, and tissue culture is required for diagnosis. The related enteroviruses are also common causes of cold symptoms; however, many of the common serotypes cannot be isolated by conventional culture techniques, and serology is unsatisfactory. No attempt was made to identify infection with enteroviruses in this study.

Coronaviruses are the second most frequent cause of the common cold but cannot be isolated on conventional culture, although they may be identified serologically. In this study, viral culture and serology was uniformly negative, although no attempts were made to identify infection with coronaviruses. These findings are consistent with the recent report of severe acute exacerbations of asthma assessed in an emergency department (11), in which over half of the patients had symptoms suggestive of a viral illness, but viral studies were also uniformly negative. Use of nucleic acid amplification techniques has confirmed the viral etiology of such symptoms in other reports in people with asthma $(8,18)$, although identifying all possible candidates for cold symptoms by these techniques is prohibitively expensive. Therefore, the symptomatic colds in this study were fairly likely to have been true viral infections despite our negative virological findings.

Nevertheless, the possibility that some of these symptomatic colds may be manifestations of allergic rhinitis was considered, especially for episodes of increased nasal symptoms and sore throat without fever (seven of the 17 cases with cold symptoms). Some apparent upper respiratory tract infections with asthma exacerbations in the study may have been because of seasonal or nonseasonal allergen exposure such as pollen, fungal allergen, dust mite and animal related allergic rhinitis, although these were not identified in these episodes as major triggers by the questionnaire. Nasal symptoms without concurrent sore throat or fever were not uncommon among the control group and may have reflected allergic or nonallergic rhinitis. In addition, one control patient described a sore throat and may have had a viral upper respiratory infection without an asthma exacerbation.

At entry into the one-year study, the history of secondhand smoke exposure was greater in subjects who were case compared with control patients (Table 1). This association is consistent with a previously reported association in children between second-hand smoke exposure and increased asthma severity (19), which would be expected to result in less stability of symptoms and increased medication needs. Possibly supporting this, we found that case patients were more likely than controls to be receiving regular inhaled steroid medications at entry into the panel study, before the case-control component to the study (Table 1). However, baseline airway responsiveness to methacholine was not increased in case compared with control patients. Environmental tobacco smoke has previously been associated with an increased risk of acute respiratory illness in children $(20,21)$ and an increased risk of wheezing during colds (22), and it is possible that this may be through a more direct effect of tobacco smoke, such as impaired mucociliary clearance.

In this study, there was an increased baseline use of inhaled steroids in those with an asthma exacerbation (Table 1). Despite the anti-inflammatory effects of corticosteroids, no effect has been shown on T lymphocyte infiltration (23), and we are not aware of previous reports showing an increase in the severity of viral respiratory infections related to inhaled steroids. Inhaled steroids have been shown in one study to prevent viral-induced asthma exacerbations in children (28), possibly by a reduction of the airway inflammatory changes caused by respiratory viral infections $(25,26)$, which are especially pathogenic in atopic individuals $(27,28)$. 
However, a recent study showed no beneficial effect (29). In the present study, the proportion of patients taking inhaled steroids and the baseline dose of inhaled steroids was not different in case patients with cold symptoms compared with case patients without colds (data not shown). Our findings suggest that the use of inhaled steroids in this study may have been more frequently prescribed to people with asthma who were prone to exacerbations, although their baseline airway responsiveness as shown by methacholine challenge was not significantly different from the control patients.

\section{CONCLUSIONS}

Our findings further confirm the importance of symptomatic colds as triggers of acute asthma exacerbations both in children and in adults. In the absence of effective immunization for the most common respiratory viral infections, there is thus a need for further studies to assess the effects of inhaled steroids and other pharmacological agents on viral-induced asthma exacerbations.

ACKNOWLEDGEMENTS: This work was supported by a grant from Health Canada. Dr Tarlo was supported in part by a Schering Plough International Respiratory Infection Task-force (SPIRIT) award.

\section{REFERENCES}

1. Jennings LC, Barns G, Dawson KP. The association of viruses with acute asthma. NZ Med J 1987;100:488-90.

2. Teo J, Vellayappan K, Yip WCL, et al. Mycoplasma pneumoniae and viral infections in childhood asthma. J Trop Pediatr 1986;32:87-9.

3. Carlsen KH, Orstavik I, Lecgaard J, Hoeg H. Respiratory virus infections and aeroallergens in acute bronchial asthma. Arch Dis Child 1984;59:310-5.

4. Johnston SL, Pattemore PK, Sanderson G, et al. Community study of the role of viral infections in exacerbations of asthma in 9-11 year old children. Br Med J 1995;310:1225-9.

5. Empey DW, Laitinen LA, Jacobs L, Gold WM, Nadel JA. Mechanisms of bronchial hyperreactivity in normal subjects after upper respiratory tract infection. Am Rev Respir Dis 1976;133:131-9.

6. Gern JE, Calhoun W, Swenson C, Shen G, Busse WW. Rhinovirus preferentially increases lower respiratory responsiveness in allergic subjects. Am J Respir Crit Care Med 1997;155:1872-6.

7. Schwarze J, Hamelmann E, Bradley KL, Takeda K, Gelfand EW. Respiratory syncytial virus infection results in airway hyperresponsiveness and enhanced airway sensitization to allergen. J Clin Invest 1997;100:226-33.

8. Nicholson KG, Kent J, Ireland DC. Respiratory viruses and exacerbations of asthma in adults. Br Med J 1993;307:982-6.

9. Beasley R, Coleman ED, Herman Y, Holst PE, O’Connell TV, Tobias M. Viral respiratory tract infection and exacerbation of asthma in adult patients. Thorax 1988;43:679-83.

10. Tarlo SM, Broder I, Spence L. A prospective study of respiratory infection in adult asthmatics and their normal spouses. Clin Allergy 1979;9:293-301.
11. Sokhandan M. McFadden ER Jr, Huang YT, Mazanec MB. The contribution of respiratory viruses to severe exacerbations of asthma in adults. Chest 1995;107:1570-5.

12. Mertsola J, Ziegler T, Ruuskanen O, Vanto T, Koivikko A, Halonen P. Recurrent wheezy bronchitis and viral respiratory infections. Arch Dis Child 1991;66:124-9.

13. Potter PC, Weinberg E, Shore SCL. Acute severe asthma: a prospective study of the precipitating factors in 40 children. South Afr Med J 1984;66:397-402.

14. Johnston SL, Pattemore PK, Sanderson G, et al. The relationship between upper respiratory infections and hospital admissions for asthma: a time-trend analysis. Am J Respir Crit Care Med 1996;154:654-60.

15. Chan-Yeung M, Manfreda J, Dimich-Ward H, et al. Mite and cat allergen levels in homes and severity of asthma. Am J Respir Crit Care Med 1995;152:1805-11.

16. Chan-Yeung M, Chang JH, Manfreda J, Ferguson A, Becker A Changes in peak flow, symptom score, and the use of medications during acute exacerbations of asthma. Am J Respir Crit Care Med 1996;154:889-93.

17. Hawkes RA. Diagnostic Procedures for Viral, Rickettsial and Chlamydial Infections. In: EH Lennette, NJ Schmidt, eds. Washington: American Public Health Association 1979:35-42.

18. Johnston SL, Sanderson G, Pattemore PK, et al. Use of polymerase chain reaction for diagnosis of picornavirus infection in subjects with and without respiratory symptoms. J Clin Microbiol 1993;31:111-7.

19. Murray AB, Morrison BJ. The effect of cigarette smoke from the mother on bronchial responsiveness and severity of symptoms in children with asthma. J Allergy Clin Immunol 1986;77:575-81.

20. United States Department of Health and Human Services. The Health Consequences of Involuntary Smoking: A Report of the Surgeon General. Pub. No (PHS) 87-8398. Washington: US DHHS, Public Health Service, Office of the Assistant Secretary for Health, Office of Smoking and Health, 1986

21. American Thoracic Society Statement on Cigarette Smoking and Health. Am J Respir Crit Care Med 1996;150:48-53

22. Cunningham J, O’Connor GT, Dockery DW, Speizer FE. Environmental tobacco smoke, wheezing and asthma in children. Am J Respir Crit Care Med 1996;153:218-24.

23. Trigg CJ, Manolitsas ND, Wang J, et al. Placebo-controlled immunopathologic study of four months of inhaled corticosteroids in asthma. Am J Respir Crit Care Med 1994;150:17-22.

24. Connett G, Lenney W. Prevention of viral induced asthma attacks using inhaled budesonide. Arch Dis Child 1993;68:85-7.

25. Fraenkel DJ, Bardin PG, Sanderson G, Lampe F, Johnston SL, Holgate ST. Lower airways inflammation during rhinovirus colds in normal and in asthmatic subjects. Am J Respir Crit Care Med 1995; 151:879-86.

26. Bardin PG, Johnston SL, Pattemore PK. Viruses as precipitants of asthma symptoms. II. Physiology and mechanisms. Clin Exp Allergy 1992;22:809-22.

27. Bardin PG, Fraenkel DJ, Sanderson G, et al. Amplified rhinovirus colds in atopic subjects. Clin Exp Allergy 1994;24:457-64.

28. Lemanske RF Fr, Dick EC, Swanson CA, Vrtis RF, Busse WW. Rhinovirus upper respiratory infection increases airway hyperreactivity and late asthmatic reactions. J Clin Invest 1989;83:1-10.

29. Wilson N, Sloper K, Silverman M. Effect of continuous treatment with topical corticosteroid on episodic viral wheeze in preschool children. Arch Dis Child 1995;72:317-20. 


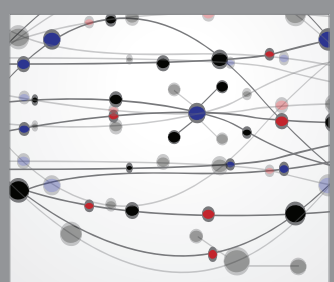

The Scientific World Journal
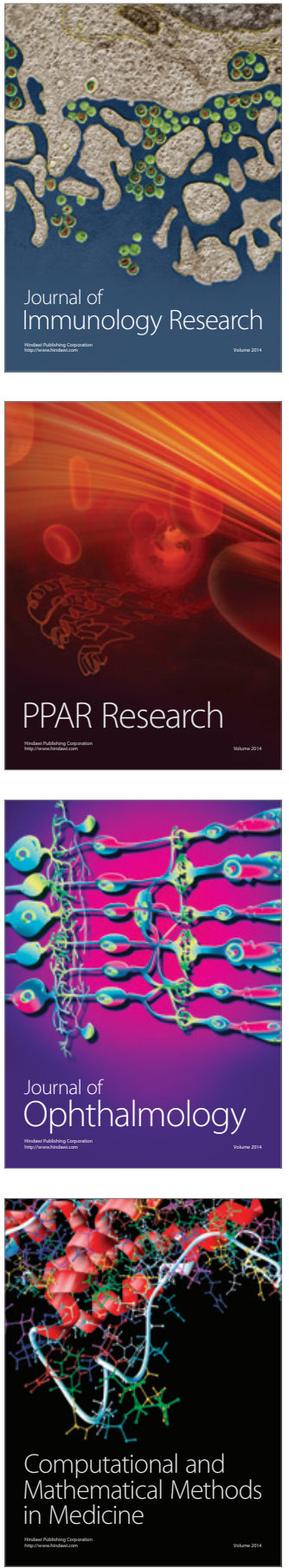

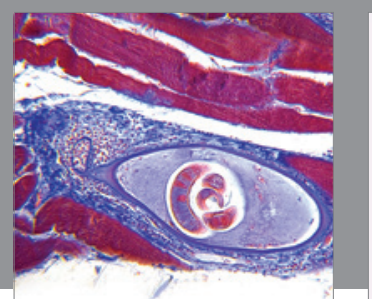

Gastroenterology Research and Practice

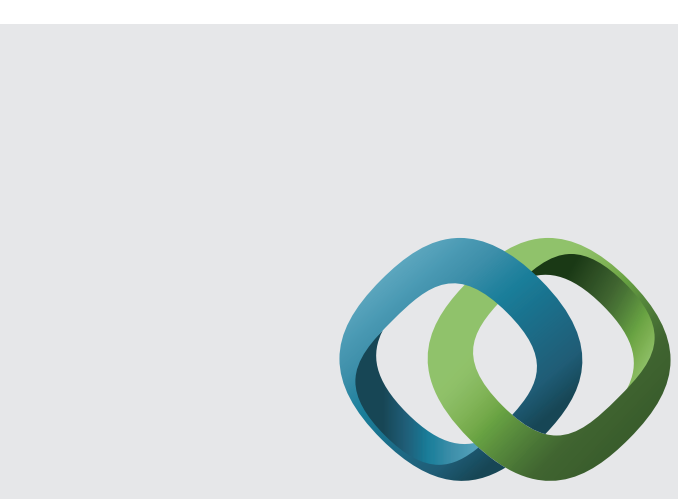

\section{Hindawi}

Submit your manuscripts at

http://www.hindawi.com
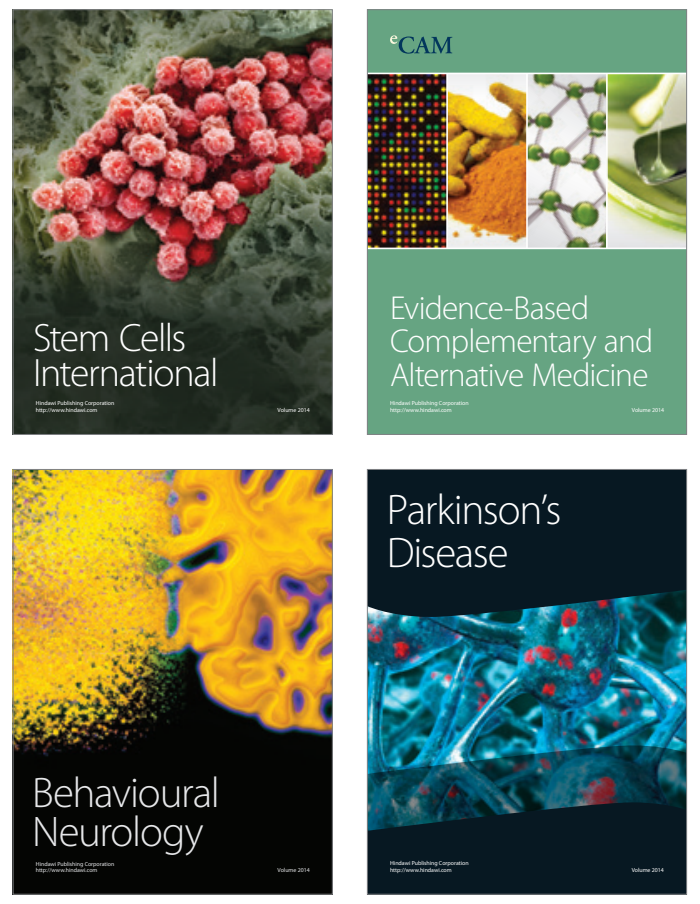
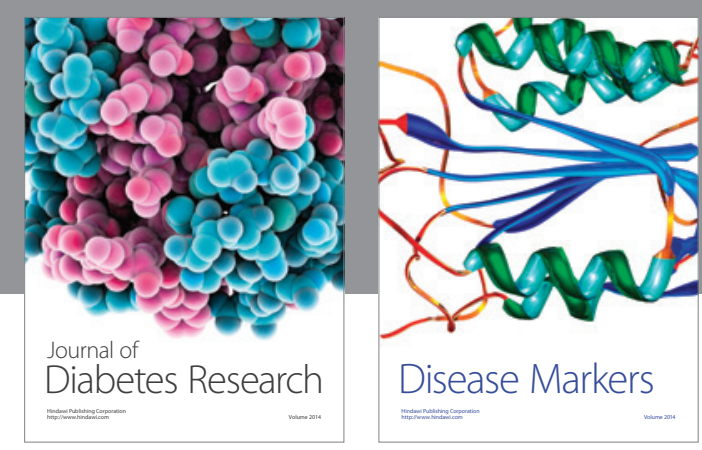

Disease Markers
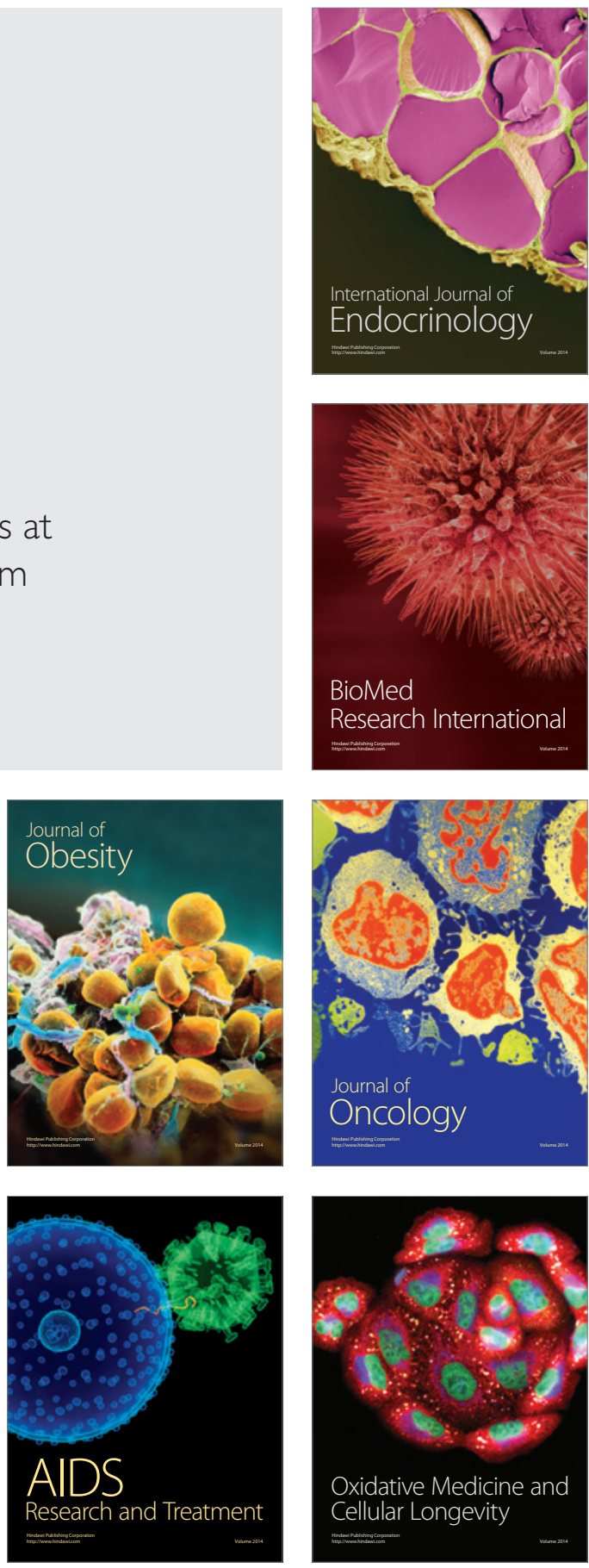